\title{
ESCALANDO VULCÕES: A RELEITURA DA DOR NO PARTO HUMANIZADO
}

\author{
Jane Russo ${ }^{1}$ \\ Marina Nucci ${ }^{1}$ \\ Fernanda Loureiro Silva ${ }^{1}$ \\ Lilian K. Chazan ${ }^{1}$ \\ ${ }^{1}$ Universidade do Estado do Rio de Janeiro (UERJ), \\ Programa de Pós-graduação em Saúde Coletiva, \\ Instituto de Medicina Social (IMS), Rio de Janeiro, RJ, Brasil
}

\section{Introdução}

Recentemente, o que se convencionou chamar de "parto humanizado" tem sido objeto de inúmeros estudos (Tornquist 2004; Diniz 2005; Souza 2005; Carneiro 2015; Hirsch 2015; Rezende 2015; Silva 2017; Mendonça 2018, entre outros), tendo se transformado em um importante núcleo da modificação na maneira de dar à luz para um conjunto significativo de mulheres, configurando um movimento social que se expressa publicamente contra o parto hospitalar tradicional, além de difundir-se massivamente nas redes sociais. Esse movimento propõe mudanças que visam desestimular o "parto medicalizado" e incentivar o uso de práticas "humanizadas" que seriam mais adequadas à fisiologia do parto. Carmen Susana Tornquist (2004) caracteriza-o como um movimento feminista, originado, como os demais movimentos feministas, nas camadas médias urbanas e intelectualizadas. Apesar dessa origem - ou por causa dela - vem se difundindo por boa parte do território nacional através de ações e programas de saúde. A autora destaca que, desde os seus primórdios, o referido movimento tem atuado em parceria com agências estatais em ações concretas que visam à modificação do atendimento ao parto dentro e fora da rede hospitalar. ${ }^{1}$

Essas transformações no modo de dar à luz estão no cerne de políticas públicas no Brasil ${ }^{2}$ e no resto do mundo. Em 1985, a Organização Mundial da Saúde (OMS) publicou um pequeno artigo intitulado "Appropriate technology for birth" como resultado da conferência (de mesmo nome) realizada 
em Fortaleza, Brasil, em que representantes de diversas categorias profissionais $^{3}$ e mães [sic] revisaram as tecnologias utilizadas na assistência ao parto, e lançaram recomendações gerais (aplicáveis, de acordo com o texto, no mundo todo) que preconizavam uma transformação completa da estrutura dos serviços de saúde, com a modificação das atitudes dos profissionais e a redistribuição de recursos humanos e físicos (WHO 1985). Posteriormente, em 1996, a OMS lançou o documento Assistência ao Parto Normal: um guia prático ${ }^{4}$ que ficou popularmente conhecido como "Recomendações da OMS". Essas diretrizes - norteadoras das práticas dos defensores da humanização do parto no Brasil - tinham como objetivo examinar as "melhores evidências disponíveis" a favor ou contra algumas práticas de monitoramento, condução e correção do "processo fisiológico do parto" e, a partir daí, estabelecer algumas "normas de boas práticas" na condução do trabalho de parto de "mulheres de baixo risco" (WHO 1996).

Mais recentemente, no início de 2018, a organização divulgou um conjunto de novas recomendações com o objetivo de estabelecer padrões globais de assistência às mulheres grávidas saudáveis, visando reduzir intervenções médicas consideradas desnecessárias e promover o conceito de "experiência de parto positiva" como um aspecto fundamental para garantir cuidados de alta qualidade no trabalho de parto e melhores resultados centrados nas mulheres (WHO 2018). As "Recomendações da OMS" são fundamentadas em um conjunto de estudos científicos, reunidos principalmente através de meta-análises realizadas pela Colaboração Cochrane, grupo independente e sem fins lucrativos que busca organizar os resultados de pesquisas na área da saúde. Tais "Recomendações" são frequentemente acionadas por profissionais e ativistas ligados ao movimento pelo parto humanizado como um argumento de autoridade estratégico para ser usado em face de práticas tidas como ultrapassadas de assistência obstétrica. Como veremos, a referência a estudos ou às "melhores evidências científicas" emergem com muita frequência nas discussões sobre parto humanizado.

Neste trabalho pretendemos discutir a forma como essa proposta de um novo modo de parir se articula com uma interpretação renovada da dor do parto. Em nossa discussão buscaremos apontar as articulações entre uma certa interpretação da dor na parturição e o ideário subjacente ao parto humanizado.

Para esta análise utilizamos o seguinte material: entrevistas, aulas de capacitação para doulas, ${ }^{5}$ blogs, sites, vídeos divulgados na internet, filmes e um e-book. Nosso foco prioritário foi o material acessado através da internet, pois acreditamos que boa parte das informações e reivindicações associadas ao movimento circula em redes virtuais. Compõem um conjunto 
de informações, opiniões e relatos personalizados que formam um mosaico disperso do qual buscamos retirar material para fundamentar nossos argumentos. Não realizamos, deste modo, uma etnografia clássica de um grupo ou de uma rede específica. Ao contrário, nesses dois anos em que dura nossa pesquisa, buscamos uma espécie de imersão no conjunto multifacetado de depoimentos, imagens e instruções contidos em blogs, redes de discussão, sites, cursos on-line, procurando captar o ideário que subjaz ao movimento que é objeto de nossa análise.

Os vídeos de parto foram assistidos coletivamente por nós. Durante a exibição fizemos anotações e posteriormente discutimos nossas observações. Algumas falas foram transcritas, mas, de modo geral, os vídeos têm poucas falas ou conversas, sendo mais frequentes gritos e vocalizações das parturientes. Optamos por não analisar os vídeos do ponto de vista da semiótica visual e sonora (cenários, cores, edição, som), pois tal análise fugiria dos objetivos do artigo. A maioria dos vídeos assistidos retratava partos domiciliares (isto é, realizados fora do ambiente hospitalar, na residência da parturiente) e via de regra compartilhava a mesma estética e o mesmo roteiro. A peculiaridade destes vídeos consistia em sua edição característica, procurando mostrar as diferentes fases do parto com destaque para o período expulsivo, combinada com uma trilha sonora e exibindo o ambiente doméstico. A presença de filhos mais velhos ou mesmo de animais domésticos (atores que não poderiam participar de uma cena de parto no ambiente hospitalar) era valorizada através das imagens. A ênfase residia na domesticidade e no parto como evento inserido "naturalmente" em um cotidiano comum.

Partindo, então, do material multifacetado descrito acima, tentaremos demonstrar como os recentes movimentos de desmedicalização ${ }^{6}$ do parto se associam à reinterpretação da dor no parto. Deste modo, estruturamos o artigo com uma breve discussão sobre a dor e alguns de seus desdobramentos, seguida por uma história da medicalização/desmedicalização do parto, para apresentarmos nosso argumento baseado no material empírico já descrito.

\section{A dor do parto como evento}

A dor é parte inseparável da vida cotidiana, podendo ser atribuída a um incontável número de fenômenos. Ela pode estar presente em ferimentos, lesões e doenças, em algumas formas de buscar diagnóstico e também em tratamentos, ${ }^{7}$ e constitui uma característica marcante de muitos processos fisiológicos normais, tais como parto e menstruação (Helman 2007). A relação entre dor e parturição é parte do senso comum - a dor sendo nor- 
malmente vista como constitutiva do trabalho de parto. Referências bíblicas são comumente acionadas, ${ }^{8}$ e as imagens visuais de partos, em cenas de filmes, seriados de TV ou outras mídias, mostram invariavelmente mulheres que gritam, suam, se contorcem.

Do ponto de vista fisiológico, a dor, enquanto experiência privada, individual, poderia ser compreendida como um "dispositivo de alerta" que tem uma importância crucial para proteção e sobrevivência do corpo em um ambiente potencialmente perigoso - uma perspectiva que a coloca como uma função biológica universal (Helman 2007). Ainda segundo este autor, diferentes grupos sociais e culturais apresentam formas distintas de reagir diante de uma experiência dolorosa. O modo como as pessoas se comportam em face de tal experiência depende não só da percepção individual da intensidade da dor, mas também das interpretações do que pode ser considerado como uma dor normal ou anormal. Assim, as definições em torno da dor tendem a variar com o passar do tempo e a ser influenciadas pelo contexto econômico e social, bem como pelas determinações culturais acerca da estrutura e da função do corpo (Helman 2007).

Avançando um pouco mais e indo além do que propõe Helman, Cynthia Sarti (2001) aponta que "toda experiência individual inscreve-se num campo de significações coletivamente elaborado" (Sarti 2001:4), na medida em que o corpo é produzido a partir de significados atribuídos pela coletividade, sendo definido de acordo com as regras do mundo social no qual se inscreve. Do mesmo modo, a dor, enquanto experiência radicalmente subjetiva, também se insere em um universo de referências simbólicas. Nesse sentido, mais do que apenas um mecanismo neurofisiológico influenciado por fatores externos ou internos, a dor deve ser considerada como produto de um amálgama de elementos fisiológicos, psicológicos, sociais e culturais.

Procuraremos, neste artigo, fugir da "armadilha ontológica" citada por Joanna Bourke (2014), evitando encarar a dor - seja a do parto, ou qualquer outra - como um evento biológico que existe em si, independente de como a experiência da dor é socialmente simbolizada. Seguindo Bourke, não consideramos a dor como uma entidade estável, um fato bruto ou uma experiência física imediata, mas sim como interpretações de um fenômeno que envolve a combinação de sensações, disposições, explicações e circunstâncias culturais.

Deste ponto de vista, portanto, a dor não seria a simples resposta a um estímulo (uma qualidade intrínseca da sensação crua), mas o modo como percebemos a experiência e avaliamos o estímulo. É uma maneira de sentir, de vivenciar e nomear uma experiência.

Bourke propõe a categoria "dor-como-evento" afirmando que esta proposição 
[...] reconhece o fato de que a ontologia da dor nunca é estável. Conforme os historiadores da ciência não cansam de repetir, a prática científica é uma ação social. Em outras palavras, identificar as características da dor envolve o trabalho de filósofos, cientistas e clínicos, assim como o de historiadores. Nós inventamos, ao invés de descobrirmos, a dor (Bourke 2014: 12). ${ }^{9}$

Considerar a dor como um evento significa que "as pessoas são ativas na sua construção em termos sensoriais, cognitivos e motivacionais" (Bourke 2014:16) ${ }^{10}$ e que "a dor só existe no ato de sua avaliação" (Bourke 2014:15). ${ }^{11}$ Nossa perspectiva, portanto, é a de que as dores são percebidas e interpretadas a partir da totalidade das experiências vividas, estando aí imbricadas as fisiologias, os estados emocionais, as crenças e a posição relacional em comunidades (Bourke 2014). ${ }^{12}$

A dor seria, desse modo, inerentemente social, uma exegese aprendida, a resposta corporal dependendo da nomeação que contém a instrução de como o corpo deve responder (Bourke 2014:20). A interação entre corpo, linguagem e modelo cultural constrói, deste modo, a dor como evento. Usando a linguagem antropológica, Sarti faz afirmação semelhante: as formas de sentir e de expressar a dor, ainda que traduzidas e apreendidas subjetivamente, são regidas por códigos culturais que sancionam os modos de manifestação dos sentimentos (Sarti 2001). A dor precisa, desta forma, ser vivenciada e expressa mediante uma gramática instituída coletivamente para que se torne inteligível e possa fazer sentido para o grupo social.

Tomamos a ideia de que a dor é "inventada" ao invés de "descoberta" - e de que ela só existe no ato de sua avaliação - com o intuito de nos afastarmos da concepção da dor do parto como algo que possa ser reduzido ou equiparado a seu substrato ou base fisiológica. Partindo deste ponto de vista é possível traçar uma pequena história de como a dor no parto tem sido, em tempos recentes, reavaliada e ressignificada - o que implicou, como veremos, ora sua evitação, ora seu controle ou mesmo sua exaltação.

Antes de seguirmos nesse caminho, porém, faremos um breve desvio para apreciar o valor moral associado à sensação, expressão, busca ou fuga da dor.

\section{Moralidade, dor e analgesia}

Muitas sociedades consideram a dor como parte de seus ritos de passagem - rituais nos quais os indivíduos adquirem uma nova identidade social (Helman 2007). Ritos de iniciação configuram uma pedagogia que vai 
do grupo ao indivíduo. O valor social atribuído ao rito dá um significado à experiência de dor e marca a forma como esta será vivida e tolerada - uma experiência que situa os indivíduos positivamente em seu mundo social (Sarti 2001).

Nesses casos, a aceitação da dor e mesmo a tolerância a ela fazem parte do próprio rito. No caso mais específico da transformação do menino em homem feito, o fato de suportar a dor infligida durante o ritual é parte integrante de sua nova identidade (Le Breton 2013; Sarti 2001). Há, portanto, uma identidade a ser construída a partir de transformações (e inscrições corporais) que se associam à atitude perante a dor.

Segundo Le Breton, "Todas as sociedades definem implicitamente uma legitimidade da dor que se antecipa a circunstâncias sociais, culturais ou físicas tidas como difíceis" (2013:110). Cita o parto como um exemplo de tais circunstâncias e afirma: "A dose de dor esperada e as formas convencionais de responder a ela são passadas de geração a geração ou por grupos de pares, e são transmitidas pelo testemunho das enfermeiras, das parteiras ou dos médicos" (2013:110).

De fato, as expectativas em torno da dor na parturição e o seu modo de expressão podem variar muito. Enquanto mulheres nos países ocidentais tendem a ter uma atitude menos positiva em relação às dores do parto, em alguns grupos, como em Tamil Nadu, no sul da Índia, esta dor pode ser bem recebida pelas mulheres, em vez de temida. Van Hollen (citado em Helman 2007) descreve que muitas das mulheres que deram à luz em hospitais do governo insistiram para que seus trabalhos de parto fossem induzidos com o uso de ocitocina. Para esse grupo, o aumento no nível de dor na parturição aumentava o nível de sakti da mulher, o poder regenerativo espiritual das mulheres e o "princípio ativo da vida": quanto mais dor, maior o nível de sakti que a mulher poderia alcançar.

Assim, a legitimidade da dor, de sua interpretação e de sua expressão está enraizada na cultura daquele que a sofre. Em seu livro, Le Breton (2013) chama a atenção para a valorização da dor (e do sofrimento) pela religião cristã em seus primórdios: a dor denotando para os primeiros cristãos e mártires a prova de devoção absoluta que os aproximava dos padecimentos de Cristo. No decorrer dos séculos, o sacrifício como prova de devoção marcou a biografia de vários santos, a dor autoinfligida levando ao êxtase espiritual. Com a tradição cristã, assistiu-se, desta forma, a uma intensa valorização moral da dor, como forma de redenção do pecado.

É somente com o enfraquecimento dessa tradição, a partir do Iluminismo europeu, e da concomitante concepção de progresso humano, que surge o que Le Breton chama de luta contra a dor: "[a] luta contra o sofrimento e, 
portanto, também contra a dor, que, sem dúvida, é sua forma mais notável, está no cerne da ideologia do Progresso" (2013:21). Bourke alinha-se a esta perspectiva, sublinhando que "[n]o Iluminismo surgem preocupações sobre a distribuição democrática de felicidade, que tornariam o alívio da dor um 'objetivo legítimo'" (2014:273). ${ }^{13}$ Afirma ainda que "[d] or e prazer foram preocupações românticas que forneceram as condições sociais e ideológicas necessárias à busca do alívio para a dor" (2014). ${ }^{14}$

A luta contra a dor se associa à procura de formas de analgesia para situações de doença, acidentes, cirurgia ou assemelhadas (como o caso do parto). É comum marcar os anos de 1846-7 como o período em que surge a analgesia na medicina, com a introdução de duas novas drogas - éter e clorofórmio. Segundo Bourke (2014), porém, formas alternativas de alívio já estavam disponíveis desde pelo menos o início do século XIX. Em sua história da dor, a autora mostra que, mesmo com o surgimento das novas drogas sendo recebido efusivamente pela medicina, a analgesia demorou a se universalizar em todos os casos nos quais parecia se fazer necessária, incluindo cirurgias. Entre os próprios médicos havia a crença de que alguns humanos eram relativa ou totalmente insensíveis à dor. Era comum se administrar anestesia a oficiais e não a soldados feridos na guerra. Do mesmo modo acreditava-se que crianças pequenas ou escravos eram insensíveis à dor. O gênero, a etnia e a classe social aumentavam o risco de a pessoa deixar de receber tratamento adequado contra a dor.

Ao mesmo tempo, havia o temor de riscos médicos ligados à anestesia, associados a ansiedades morais e perigos espirituais. No tocante aos riscos médicos havia, por exemplo, a crença de que a dor fosse um componente necessário ao processo curativo.

A "não-naturalidade" do entorpecimento dos sentidos incentivou as dúvidas sobre o valor de erradicar a dor. "Afinal, não são as sensações [...] uma função natural do organismo vivo?", perguntava um médico em 1851. Ele advertia: "Suspendê-la por meio de agentes artificiais é zerar as ordenações da natureza" (Bourke 2014:279).15

O risco médico, evidentemente, se associava ao risco moral, na medida em que a obediência a uma ordenação natural seria moralmente desejável. Segundo Bourke, o alívio da dor atingia o cerne das crenças acerca do valor da coragem e do autocontrole. No caso dos cirurgiões, surgia a dúvida: “Um médico ponderou: será que a disponibilidade de anestésicos viria a erradicar as qualidades mais viris e audazes da confraria cirúrgica, transformando-os em meros 'efeminados'?"16 (2014:280). 
Também estar-se-ia retirando dos pacientes a oportunidade de demonstrar seu valor e coragem.

Nas palavras de um artigo intitulado "Como suportar a dor", [...] "todos deveriam preparar-se para suportar corajosamente uma certa quantidade de sofrimento [...] De fato, era dever dos médicos e cirurgiões incentivar a coragem dos pacientes. Nas palavras de um cirurgião de câncer que defendia a cauterização, "sua 'causa final' moral era desenvolver neles... o heroísmo!" (Bourke 2014:281, grifo da autora). ${ }^{17}$

Cabe assinalar que os valores associados ao enfrentamento da dor, como a coragem - que, como vimos, é parte integrante de ritos de passagem em sociedades tribais - permanece extremamente relevante em determinados grupos sociais, o exemplo mais marcante sendo o de certo tipo de desportistas (Le Breton 2013). Em sua pesquisa sobre ultramaratonistas, Isabel Conceição (2018) fala da necessidade, entre os sujeitos pesquisados, de "transcender o sofrimento" e os limites do corpo. Surge também a ideia de superar a sensação de sofrimento "para atingir o prazer do percurso e a linha de chegada" (Conceição 2018:25-6). De fato, a noção de superação atravessa o discurso dos ultramaratonistas. Como diz um dos participantes da pesquisa: "Vai doer, vai requerer dedicação, vai requerer força de vontade, vai requerer sacrifício, mas quando chegares ao teu objetivo, vai valer a pena" (2018:45). Ao mesmo tempo há um aprendizado nas maneiras de doer.

Não apenas as técnicas e estratégias de superação do estar-em-dor são construídas e aprendidas no coletivo de ultramaratonistas e na interação com informações e profissionais de saúde, mas o próprio doer é aprendido dentro do coletivo. É o grupo social que determina a legitimidade de seus sofrimentos (Conceição 2018:91).

É importante ressaltar que a superação dos próprios limites e da dor física leva, para muitos dos participantes, a uma transformação de si, como afirma a autora.

Atravessar o sofrimento, doer sem ser doído, promove no corredor de ultramaratona uma transformação tão profunda que esse doer é marcado por um importante uso social: o aprimoramento de si. Não aprimoramento físico, mas sim o aprimoramento moral porque [...] a ultramaratona é uma atividade em que a dimensão mental/moral é mais valorizada do que seu aspecto corporal/ físico (Conceição 2018:86). 
Sintetizando a discussão e articulando a dimensão moral com a dor física, podemos pensar em duas vertentes não excludentes da dor: a primeira, como sacrifício - e no caso dos cristãos, como redenção dos pecados - e como prova de bravura e coragem transportando o sujeito para um patamar superior. Por esta segunda perspectiva, evitar a dor significaria uma falha moral. Estas duas vertentes, que eventualmente se superpõem, evidenciam um enquadre moral no que tange à dor no parto: de que modo a evitação ou o enaltecimento da vivência da dor no processo da parturição estão entretecidos com as concepções de sacrifício, bravura, coragem e autocontrole?

Passaremos a delinear brevemente como a medicina obstétrica se articulou ao processo de manejo e ressignificação da dor ao longo do tempo.

\section{Medicalização e desmedicalização do parto: caminhos da humanização}

Desde a Antiguidade, o parto era compreendido como assunto exclusivo de mulheres. Conceitualmente, o nascimento fazia parte da ordem natural do universo e o parto era uma contingência pela qual as mulheres tinham que passar. Sua atitude então revelava seu caráter, e natimortos ou bebês defeituosos indicavam uma falha moral dos pais aos olhos de Deus (Arney 1982; Shorter 1997).

No século XVI, no Hôtel-Dieu, na França, teve início um curso para parteiras e, consequentemente, uma colaboração entre elas e os médicos através da observação dos partos. Um século mais tarde se consolidava o conceito racionalista corpo-máquina, e a função dos médicos no parto, com o auxílio de instrumentos - a saber, o fórceps - consistia em "otimizar" o funcionamento da máquina (Arney 1982:24-25). O "parto científico" se expande para a Inglaterra e, no início do século XVIII, algumas mulheres da burguesia em ascensão optam pela assistência de parteiros em hospitais. A saúde das crianças se torna um dos objetivos obrigatórios da família sendo ela o agente mais constante da medicalização. A mulher e sua prole são centrais neste projeto, uma das consequências sendo a progressiva medicalização do corpo da mulher (Chazan 2005; Rohden 2000). Em fins do século XIX, nos Estados Unidos, a ciência foi muito mais importante para o estabelecimento da medicina como profissão do que na Inglaterra, tendo sido utilizada como pedra angular das grandes escolas médicas. Conforme aponta Chazan, 
O parto científico realizado por médicos sublinhava a importância da segurança de partos realizados por homens [...] havia a associação do parto natural com uma "prática dos selvagens" [...] [e] a noção de que, com a civilização avançando, a "natureza" necessariamente se retraía e as mulheres perdiam a habilidade "natural" de parirem com o mínimo de ajuda [...] nos Estados Unidos, a patologização do parto adquiriu uma conotação positiva. Definitivamente, as mulheres americanas não queriam mais ter partos como as selvagens (Chazan 2005:97).

A formação da obstetrícia como profissão nos Estados Unidos foi constituída em interação constante com a medicalização e a patologização da gravidez. Em 1842 foi utilizada pela primeira vez a anestesia com éter em um parto. Na mesma época, o uso de ergotamina visando à aceleração do parto contribuía para a sua medicalização: os riscos de tetanismo e de uma ruptura uterina pelo uso da droga tornavam indispensável a presença de médicos acompanhando a parturição (Arney 1982:44). Podemos, portanto, afirmar que a formação da obstetrícia como profissão médica e a patologização do parto foram co-construídas. ${ }^{18}$

De acordo com Peter Conrad (2007), entretanto, todo processo de medicalização é irregular, tem idas e vindas, percorrendo caminhos surpreendentes e muitas vezes divergentes. Uma dessas vias, que vai nos interessar sobremaneira na medida em que caminha no sentido de uma desmedicalização, surge com a escola de pensamento liderada por um obstetra, Grantly Dick-Read, na Inglaterra dos anos 1930. ${ }^{19}$ Preocupado com o sofrimento provocado pelo medo e pela dor no parto, ele sublinhava a importância de influências culturais e de "superstições" que estariam na raiz desse sofrimento. O médico fazia referência à "síndrome medo-tensão-dor", na qual a associação entre parir e sofrer era atribuída a fatores socioculturais, reproduzidos pela tradição escrita e oral (Salem 2007). Com o intuito de tornar o parto menos sofrido e facilitar a colaboração da mulher, advogava o treinamento das gestantes com técnicas de relaxamento, bem como sua educação para o parto. A partir deste treinamento, a mulher estaria preparada para "não perder" o controle das emoções durante o trabalho de parto, reinterpretando as contrações uterinas não como dor, mas como um trabalho muscular apenas (Salem 2007).

Algum tempo depois, a escola soviética de Platonov, calcada na técnica de condicionamento pavloviana, também buscaria trazer tranquilidade e relaxamento para a mulher no decorrer do parto. Ambas focalizavam a dor no parto e os meios para minorá-la, utilizando o conceito da dor bidimensional. Diferentemente do conceito de dor unidimensional, em que a resposta fisiológica a um estímulo físico se situa no espaço contido do corpo, na dor 
bidimensional existiria uma divisão entre a sensação original e o componente psíquico. A dor assim conceituada tem lugar na ecologia "sócio-psico-bioquímica da mulher" (Arney 1982:213).

A técnica de Platonov, logo conhecida como "parto sem dor" (PSD), se expandiu na França com Lamaze, Vellay e Chertok. Marjorie Karmel, que tivera seu parto com Lamaze na França, foi a responsável pela difusão do método nos Estados Unidos nos anos 1950-60 com seu livro Thank You, Dr. Lamaze: A Mother's Experiences in Painless Childbirth (Arney 1982:215).

Desde essa época, já havia a preocupação com o uso abusivo de tecnologia no parto e com a interferência médica desnecessária. De acordo com Tornquist (2004), estes críticos "de dentro" da obstetrícia questionavam a submissão das mulheres às rotinas e normas médicas, o excesso de intervenções sobre seus corpos como justificativa para aliviar as dores do parto, bem como a separação do bebê de sua mãe e as técnicas artificiais de nutrição.

As duas escolas, com suas variações, sempre se basearam na bidimensionalidade do parto, tendo em comum uma releitura das suas dores. Além de Dick-Read e Lamaze, considerados "pais fundadores", três personagens foram emblemáticos nos desdobramentos desse ideário, dois dos quais obstetras. Foram eles Frédérik Leboyer, Michel Odent e Sheila Kitzinger, esta última com formação em antropologia social.

Vale assinalar que esses novos atores na cena obstétrica compõem o que Tania Salem designou como "pós-parto sem dor" (pós-PSD). Não se trata mais (ou se trata menos) de evitar ou minorar a dor inerente ao parto, mas de atacar o caráter tecnicista, frio e mesmo violento do parto médico-hospitalar tradicional, buscando apontar para uma forma mais natural e até mesmo prazerosa de parturição. Essas novas abordagens sustentavam o posicionamento crítico de seus antecessores, mas em um marco libertário, no qual extrapolavam a ênfase na dor e no sofrimento e se apresentavam como mais inovadoras e modernas. Tornquist (2004) sugere que a rejeição à normatividade do método e à autoridade do médico-instrutor sobre a parturiente-aprendiz no PSD, por parte dos seus sucessores, tenha propiciado uma mudança de sentido do que hoje se entende por "parto sem dor": o termo passou a ser usado na obstetrícia convencional como sinônimo de parto com analgesia. Nas palavras da autora,

Talvez este tipo de crítica tenha contribuído para que a geração contracultural, dos anos 60, tivesse apagado suas relações de filiação com o PSD, ao passo que, do ponto de vista das correntes obstétricas e políticas conservadoras, o processo de apagamento da memória tenha se dado a partir da introdução da analgesia peridural e da operação cesariana que passaram a reivindicar, para si, o monopólio da abolição da dor (Tornquist 2004:118). 
Temos aqui um aprofundamento da via desmedicalizante inaugurada com Dick-Read, ou uma nova volta no "parafuso" da medicalização. São esses novos atores que fornecerão os fundamentos mais importantes do "parto humanizado" que vai surgir como movimento nas últimas décadas do século XX. De fato, no início da década de 1970, na França, Leboyer, em seu livro Nascer sorrindo ${ }^{20}$ desvia a atenção para o recém-nascido, em especial para o "sofrimento infligido ao bebê no nascimento", defendendo o "nascimento sem violência" como uma "filosofia de vida" (Salem 1987:71). A proposta de Leboyer era de explícita inspiração oriental, criticando a tecnologização do parto e entronizando o "natural", a "natureza" e as sociedades "não corrompidas" e "contaminadas" pelo social (Salem 1987:73).

Nos anos 1980, Michel Odent, obstetra como Leboyer, radicaliza algumas de suas propostas. Enfatiza o conhecimento "instintivo" e "inato" das mulheres acerca do parto. Compreende o nascimento como uma experiência sexual, pretendendo desmedicalizar tanto quanto possível a gravidez e o parto. Seu discurso consiste basicamente em uma "denúncia ao imperialismo mundial do tecnicismo" (Salem 1987:73). Propõe a subordinação da lógica e da razão à emoção e ao instinto. Sua tese central é a de que o parto e o nascimento são "partes integrantes da vida sexual e emocional dos cônjuges" (Odent 1984 citado em Salem 1987:74). Inicialmente, sua proposta estava em continuidade com a teoria de Leboyer; gradualmente, contudo, se afasta dela e acentua a crítica à medicalização, atribuindo maior poder às parteiras, por considerar que "as mulheres são naturalmente dotadas de sensibilidade" para o atendimento de parturientes. Equipara o nascimento ao orgasmo e objetiva modificações na arquitetura da sala de parto, significativamente designada por ele como salle sauvage. Sua proposta implica - ao contrário do método do parto sem dor e do psicoprofilático - o "abandono do cérebro superior" e do controle como elementos facilitadores do parto, assim como o contato da parturiente com "seu eu instintivo interior". A proposta de Odent consiste na "entronização do preceito de antinormatividade", concedendo supremacia ao "instinto" (Salem 1987:74-76).

Tornquist chama a atenção para o fato de que Odent, ao recuperar as ideias propostas por Leboyer, o faz a partir da construção de "uma argumentação que se pretende mais científica e interdisciplinar, baseada em dados da ciência e em uma declarada interlocução com a comunidade científica hegemônica" (Tornquist 2004:122).

Radicalizando a inflexão singularizante e psicologizante de Odent, Sheila Kitzinger (1981 citada em Salem 1987:80), antropóloga social, entende o momento do parto como resultante da "educação e do passado da mulher". Inclui a "experiência subjetiva do parto" no casamento, e 
escreve manuais "não prescritivos" ${ }^{21}$ Contrapondo-se à "rigidez disciplinar do parto sem dor", preceitua flexibilidade na sua condução e considera o nascimento um "ato criativo", sublinhando a singularidade e a variedade de possibilidades subjetivas.

É importante acompanhar as inflexões que o movimento desmedicalizante vai seguindo no decorrer do século XX: enquanto Dick-Read e Lamaze sublinhavam a necessidade de "reeducar e conscientizar a classe médica" e não questionavam a centralidade dos médicos no parto - incidentalmente, aos quais também era delegada a preparação das mulheres visando a um parto indolor - nos discursos do ideário pós-PSD, a centralidade da figura do médico é deslocada em diversos sentidos, outros profissionais são convocados e os médicos "perdem o monopólio de preparação da gestante" (Salem 1987:88).

Há deslizamentos no que tange à concepção do "psicológico" no parto. Conforme assinala Chazan,

[P]ara Dick-Read e Lamaze, o "psicológico" é um meio para alcançar-se um fim: a analgesia do parto. No ideário pós-PSD, o "psicológico" é um fim em si [...] gravidez e parto como momentos de introspecção, crescimento e aperfeiçoamento pessoal, configurando [...] uma noção romântica de Bildung ${ }^{22}$ (Chazan 2005:17, grifos da autora).

O discurso que se legitima por meio de regras universalmente aplicáveis é deslocado por outro, que supostamente repudia qualquer tipo de normatividade. Dick-Read e Lamaze ministravam aulas teórico-práticas; Leboyer, de modo mais ambicioso, propõe uma "filosofia de vida"; Kitzinger prescreve "flexibilizar" métodos; Odent gradualmente adere à proposta de antinormatividade radical (Salem 1987:93). Salem aponta para uma inflexão importante promovida pelo pós-PSD em relação ao PSD: a psicologização dos sujeitos. Segundo a autora, o escopo e o estatuto do psicológico sofrem alterações significativas. Há uma ampliação do que é compreendido pela categoria "psicológico" e, portanto, daquilo que "deve ser trabalhado". Em suas palavras, "o psicológico se autonomiza tanto da fisiologia quanto do social, e passa a ser representado como domínio irredutível regido por leis próprias" (Salem 2007:75).

Estamos chegando na composição do ideário do parto humanizado que, parece-nos, ultrapassa (embora não inteiramente) a etapa de psicologização apontada por Salem no pós-PSD. De fato, ainda que a relação entre o "parto humanizado" e os movimentos de revisão do parto seja direta, já que ambos se unem em torno do mesmo ideário individualista-libertário, incorporando valores como a exaltação de uma "natureza feminina" e a inspiração oriental 
nos cuidados com o corpo e com a saúde, o movimento pela humanização da assistência ao parto no Brasil apresenta algumas distinções quanto aos movimentos anteriores.

Além de afirmar que as ideias em torno das dores do parto se modificam ao longo das gerações, Tornquist assinala outros pontos de diferenciação, a saber: a vinculação com distintos movimentos sociais, a ênfase em políticas públicas e a incorporação de diferentes categorias profissionais que também passam a reivindicar um espaço no campo da assistência ao parto (Tornquist 2004).

As psicólogas que compunham boa parte dos profissionais encarregados da preparação para o parto são substituídas por outras personagens, dentre as quais estão as doulas, as enfermeiras e as obstetrizes que irão dar suporte físico e emocional (e não mais apenas psicológico) à mulher que pare. A psicologia é substituída pela "medicina baseada em evidências", ${ }^{23} \mathrm{O}$ que representa uma importante virada no processo de desmedicalização, curiosamente submetida ao conhecimento médico. ${ }^{24}$

O corpo passa para o primeiro plano: assiste-se a um deslocamento da "interioridade psicológica" para a "expressividade corporal" que implica exteriorização e "corporificação" das emoções, a "liberação total" ocorrendo mediante a "liberdade de movimentos" e da "perda de controle".

É importante enfatizar que a desmedicalização do parto emerge da própria obstetrícia. Outro aspecto a sublinhar é que ela começa em torno da dor e da necessidade de controlá-la. No caso que estamos discutindo aqui, ou seja, de uma nova fase do processo de desmedicalização que surge com o ideário do parto humanizado, trata-se do manejo e não do controle ou da supressão da dor. Como vimos acima, entram em cena novos personagens, como a doula e a obstetriz, ou a enfermeira obstétrica. A importância das redes sociais também não pode ser subestimada. ${ }^{25}$ Estas abriram uma possibilidade anteriormente inexistente, a saber, de as gestantes se informarem em rede composta por gestantes "leigas" (e não mais, necessariamente, com a medicina, ou individualmente, na rede de relações pessoais próximas). Estes são alguns dos elementos que propiciam o surgimento de uma curiosa bricolagem que mescla visões "alternativistas" com as evidências científicas (normalmente citações da medicina baseada em evidências), que supostamente as legitimam. Seu epítome se encontra na expressão "ocitocina, o hormônio do amor". ${ }^{26}$ 


\section{A dor na experiência do parto}

A análise de vídeos e relatos de parto ${ }^{27}$ no ideário do movimento da humanização nos permite pensar na parturição como uma experiência ritualizada. Utilizando-nos do conceito de Turner (1987), este seria um ponto de transição, ou de liminaridade, que marca o momento em que a mulher gestante finalmente se tornará mãe. Assim, o parto é descrito como uma experiência transformadora, ${ }^{28}$ um evento quase transcendental, que deve ser vivido pela mulher em toda a sua intensidade sensorial, afetiva e moral, a partir do qual a parturiente e a criança estabelecerão intensos vínculos ao mesmo tempo corporais e emocionais que serão responsáveis pela saúde física e mental e pela futura felicidade do bebê.

O trecho abaixo, de um site sobre parto humanizado, descreve-o como essa experiência profunda, de descontrole, mas, sobretudo, como um momento liminar, de morte e nascimento.

A força que invade o corpo feminino quando o bebê está descendo, já coroando, é de uma intensidade descomunal. Há um desejo incontrolável de expelir, de expulsar... de morrer. Sim, a mulher vai morrer. E o bebê, imerso e integrado no mundo uterino, também vai morrer, pois é preciso entregar-se à morte para renascer em vida.

Nesse momento acontece uma profusão de registros na vida dos seres que nascem. A mulher exala amor e emoção. Mira o bebê nos olhos, beija-o. Nasce uma mãe (O parto é uma boa hora - site Parto do princípio - http://www.partodoprincipio.com.br/relatos-de-parto, acessado em 14/11/2018).

O parto como experiência física deve ser vivido em sua plenitude, nenhuma sensação deve ser excluída - e a dor, como sensação, integra essa experiência. Não se trata, portanto, de evitar a dor, como foi o caso do movimento do parto sem dor do pós-guerra, mas de vivê-la em sua plenitude, como parte de uma experiência fantástica, transformadora e libertadora. A dor, na plenitude do parto, pode perfeitamente se transformar em prazer.

O protagonismo - ligado à autonomia, ao consentimento e à informação, já que as escolhas devem ser informadas pelas "melhores evidências científicas" - é o que transforma a dor, articulando-a ao prazer (bem-estar, felicidade). A crítica ao poder médico se associa a uma determinada leitura feminista que visa empoderar a mulher através do protagonismo no momento do parto. Patriarcado e medicina se confundem, e a mulher supostamente deve se libertar de ambos através de seu poder corporal de dar à luz suportando a dor. 
O protagonismo corporal, portanto, tem um claro sentido moral.

[As] dores e dificuldades no parto teriam um sentido a ser revelado [...] O parto é sem dúvida uma oportunidade ímpar de nos desenvolvermos por inteiro e carregarmos por todo e sempre, mães e filhos, a grandeza embebida nesse processo (site "Formação de doulas do despertar do parto" in Silva 2017:70, grifos nossos).

Porque é muito grandiosa essa experiência do parir. [...] Uma experiência da gente encontrar com o nosso próprio limite ir além, e descobrir que a gente tem muito mais do que a gente pensava, e colocar o nosso filho no mundo com as próprias forças. Meu Deus, é uma experiência que é uma oportunidade, na verdade, e a gente não pode perder, não deveria perder (Entrevista de uma doula em Silva 2017:94, grifos nossos).

Nos grupos de discussão dentro e fora da Internet surgem os termos "coragem", "conseguir", "vencer" ou "fracassar". Em um dos vídeos de parto humanizado a que assistimos, a obstetriz, tentando encorajar uma parturiente já sem forças, usa a imagem de escalar uma montanha, dizendo: "Um parto é como escalar o Everest".

Não por acaso, é comum em relatos de parto a referência à "hora da covardia", momento em que a parturiente, já cansada do trabalho de parto e das dores, pensa em desistir.

Quando dizem que existe "a hora da covardia", a hora é essa! Você fica meio alucinada, bate o medo de não conseguir, você meio que desespera, afinal, é sua filha, né?! E você começa a pedir coisas absurdas, começa a pedir anestesia, pedir tudo. [...] mas aí o jogo muda na mesma hora, todo esse sentimento vai embora e então você vira bicho, você tira forças de um lugar que você nem sabia que existia e simplesmente começa a fazer uma força que você nunca pensou que teria. Mas tem, e como tem! (http://mundodelilica.wixsite.com/posteridade/single-post/2015/05/27/relato-do-nosso-parto).

Quando você pensa em desistir, quando você se pergunta "por que eu fui inventar de parto normal?", quando você esbraveja com o seu parceiro "por que você colocou esse muleque em mim?" quando você grita "eu vou morrer" e "eu não vou conseguir", o "quase" vem... e ele vem através de uma força que você nunca imaginou ter. É surpreendentemente mágico. [...] Em vários momentos deixei de acreditar em mim e falei "eu não vou conseguir". Até que o grito veio. A leoa surgiu. A força tomou conta do meu corpo. E meu filho nasceu. Eu consegui. [...] Somos fortes! Somos perfeitamente capazes! [...] O segredo é acreditar em você, mesmo na hora da covardia, quando você grita 
que não vai conseguir, apenas acredite em você, e tudo dará certo. Hoje vejo a dor totalmente com outros olhos. Posso até dizer que já me esqueci da dor!! (http://www.wanessapickler.com/portfolio/partosnascimentos/275553-parto-hospital-modelo-sorocaba-alyne. Acesso em 14/11/2018, grifos nossos)

O parto aparece, nesses relatos, como um momento de superação da "covardia" e da dor, ao mesmo tempo em que há a valorização da força e do corpo feminino. Em um mesmo sentido, Claudia Rezende fala na "dimensão sacrificial da maternidade", afirmando que "a forma 'natural' de parir era mais valorizada por refletir um modelo de maternidade assentado no sacrifício da mãe - que suportaria as dores - pelo filho" (2012:845). Há, portanto, um componente moral forte na sustentação da ideia de um parto realizado com as próprias forças e também na atitude normalmente contrária a qualquer tipo de analgesia química. A dor e o esforço corporal dizem respeito a essa "experiência grandiosa", quase como se houvesse a necessidade de passar pela dor, isto é, da dor como parte do prazer ou da felicidade de se ter um filho.

Além disso, refere-se à ideologia e à prática do parto humanizado a afirmação de uma natureza humana - e feminina - instintiva que, quando pode se expressar livremente através do corpo da parturiente, leva a um parto bem-sucedido. Como vimos também, isso só é possível se o enquadramento ${ }^{29}$ médico tradicional for abandonado - um processo que mais acima apontamos como de "desmedicalização". O parto desmedicalizado é, assim, um evento "natural" - a comparação com outros animais mamíferos e com mulheres de sociedades "primitivas" é comum. Queremos argumentar aqui que o abandono do enquadramento médico implica a adesão a um outro tipo de enquadramento, bem diferente, mas nem por isso menos poderoso.

O grande número de vídeos de partos humanizados ou domiciliares, os relatos de parto publicados nas redes sociais, os vídeos e os blogs de doulas ou outros tipos de profissionais ligados ao movimento do parto humanizado que buscam orientar as gestantes sobre como viver o próprio parto contêm um sem-número de indicações a serem seguidas para que o evento tenha um bom desenlace.

Inicialmente - sobretudo no caso dos blogs e dos vídeos de esclarecimento - encontramos um relato razoavelmente organizado sobre o desenrolar do parto - suas diferentes fases, o que esperar de cada uma delas e, mais ou menos, como se comportar. As orientações acerca do tipo de comportamento a ser adotado seriam como "diretivas de segunda ordem", que admitem um grau razoável de flexibilidade e escolha. Melhor seria talvez dizer que ter flexibilidade é a própria diretiva, ou seja, o limite entre o que a mulher pode fazer e o que deve fazer é bastante fluido. 
Lembramos aqui do artigo de Sérvulo Figueira - "O 'moderno' e o 'arcaico' na nova família brasileira" (1986) - em que o autor propõe a existência de dois tipos de regra: uma "regra de primeiro grau" e uma "regra de segundo grau". A primeira emana de uma autoridade exterior ao sujeito, determinando de fora o que ele deve fazer. Por exemplo: "No sinal vermelho pare, no sinal verde, ande". No caso da regra de segundo grau o indivíduo deve optar pelo melhor caminho a seguir. O exemplo dado por Figueira é muito interessante e nos serve de argumento para nossa alegação: "No sinal, quer ele esteja verde ou vermelho, pense e decida" (1986:25). Ora, caso se decida seguir no sinal vermelho, poderemos ser multados, causar um acidente, atropelar e matar alguém etc., ao passo que o sinal verde indica ser esta a boa hora de seguir. Em outros termos, o exemplo escolhido por Figueira, se tomado ao pé da letra, leva a uma situação em que o sujeito deve fazer a escolha certa para seu próprio bem (parar no sinal vermelho para evitar um acidente).

No caso que estamos tratando aqui, um dos mais fortes argumentos que sustentam a condenação do que se tem considerado como violência obstétrica é a falta de protagonismo da mulher no próprio parto. ${ }^{30}$ No parto medicalizado, o obstetra é quem conheceria o caminho a seguir. À mulher caberia apenas obedecer às "regras de primeiro grau" enunciadas pela medicina, o que frequentemente pode ser sentido como humilhação. No caso do parto humanizado, a mulher deve escolher como deseja encaminhar o seu próprio processo. Essa escolha, aliás como qualquer outra, é limitada e obedece a certos enquadramentos, devendo ser orientada, em primeiro lugar, pelas "melhores evidências científicas" e, em segundo, pelos relatos de outros partos a que se tem acesso e pelas diretrizes que lhes são oferecidas pelos novos especialistas, em grupos de orientação ou em redes sociais. Por exemplo, a opção por uma "cesárea eletiva"31 seria uma má escolha ou uma escolha "não informada". ${ }^{32}$ Isto porque, no ideário do movimento, a cesárea não é considerada parto, é uma intervenção cirúrgica para a extração do bebê, que apresenta riscos do ponto de vista das evidências científicas, e não deve, portanto, ser realizada de forma indiscriminada (Silva 2017). ${ }^{33}$ De modo semelhante, receber ou não anestesia não é exatamente uma questão de livre escolha, já que as mesmas evidências científicas tendem a não recomendá-la. ${ }^{34}$

Uma vez feita a escolha pelo parto natural sem nenhuma (ou a menor possível) ingerência médica, cabe à mulher um conjunto de outras decisões, a primeira delas sendo onde e com quem parir: faz-se necessário buscar uma maternidade e/ou equipe "humanizada" ou, se for o caso, parir em casa, o que exige determinados pré-requisitos e procedimentos a adotar. As escolhas 
seguintes apresentam maior flexibilidade. Com exceção da condenação expressa da cesárea desnecessária, da episiotomia, ${ }^{35}$ do enema, ${ }^{36}$ do jejum obrigatório, da tricotomia, ${ }^{37}$ da posição litotômica ${ }^{38}$ e do uso indiscriminado da ocitocina, as demais diretivas são soft: dependendo das diferentes etapas do parto, a mulher pode/deve andar durante o trabalho de parto, dançar, se alimentar (dando preferência a determinados tipos de alimentos), movimentar-se sobre uma bola de borracha, tomar um banho morno de chuveiro, ouvir música, entre outras. ${ }^{39}$ Há diretivas mais categóricas ou incisivas, como os tipos de força a serem feitos em diferentes momentos e a posição que não deve ser assumida durante a contração.

Nos "pródromos" e nas fases "latente" (contrações irregulares e de fraca ou moderada intensidade) e "ativa" (contrações mais fortes e regulares) do trabalho de parto, a parturiente não deve permanecer deitada em posição litotômica e/ou fazer força, mas procurar seguir os "3 Rs": "respirar para deslocar a atenção da dor", "rebolar para ajudar o bebê a encaixar" e "relaxar para abrir o corpo"; já na "fase de transição" (a fase relatada como de maior dor do parto), a mulher precisa ser lembrada "que este é o pico da montanha, que ela trabalhou muito bem até agora e que logo virá o final do parto, o bebê em seus braços", e ser estimulada a "transformar a dor e o sentimento de autopiedade em autonomia e força para terminar o parto" (Notas e materiais de campo Silva 2017). Os modos de sentir a contração e interpretá-la fazem parte do autocontrole corporal, e incluem diretivas em relação à dor. A mulher pode, ou deve, gemer ou gritar, mas há um modo específico para fazê-lo de forma a facilitar a abertura da vagina: o som emitido é chamado "vocalização". ${ }^{40}$

É importante destacar o papel organizador da dor na produção do enquadre do parto instintivo e natural. No curso on-line a que tivermos acesso, ministrado por uma doula ${ }^{41}$ a dor do parto é apresentada como parte da própria ordenação do trabalho de parto, pois é fisiológica e tem uma razão de existir: "A dor nos traz para o nosso corpo". ${ }^{42}$ A palestrante procura ensinar as gestantes a distinguir as diferentes intensidades e modulações da dor durante o parto, isto é, a identificar o próprio desenrolar do processo através da dor.

Tem uma fase inicial, chamada pródromos, que ainda não é parto, é um ensaio geral que está preparando o corpo para o grande evento. [...] o Norte pra ir para a maternidade é quando estiver com 3 contrações a cada 10 minutos [...] só que essas contrações têm que durar pelo menos 40 segundos, não adianta uma contraçãozinha de 5 ou 10 segundos e de repente uma mais forte, porque ainda está irregular e não é uma fase verdadeira de trabalho de parto. ${ }^{43}$ 
Quando vem a dor, na fase ativa, que é a fase verdadeira do trabalho de parto acontecendo, a imensa maioria das mulheres tende a colocar o tronco pra frente, porque dói menos.

Tem um momento do parto, que é o momento de maior dor, que é a fase de transição, transição entre a fase ativa do parto e o expulsivo [...] é o momento da morte e do renascimento [...] e, nesse momento, a grande coisa que precisa acontecer dentro da gente é virar a chave, sair do lugar da vítima e assumir o lugar da guerreira.

No momento do expulsivo [...] no final da dilatação do trabalho de parto, eu senti que o bicho estava pegando muito, era uma intensidade muito grande da dor da contração [...] e aí começa a vir uma vontade instintiva de empurrar e fazer força.

A dor funciona, assim, segundo palavras da palestrante, como uma voz interna, instintiva, que guia a mulher na tarefa de ajudar o bebê a nascer e que, portanto, é uma aliada.

Se a gente ouvir o nosso corpo, a gente sabe o que ele está pedindo e a gente sabe o que é pra fazer [...] é acompanhar a fisiologia do corpo no que ele está nos pedindo, e a mensagem que ele traz é através da dor.

Nesse processo fisiológico da parturição, ela cita a liberação e a ação de hormônios "lindos e amorosíssimos", como a ocitocina e a endorfina, que estão associados à fruição de sensações físicas que produzem alegria e êxtase - a mesma sensação, segundo ela, de atletas e maratonistas (ou mesmo de pessoas comuns que praticam alguma atividade física), em que os músculos "gritam de dor" ao mesmo tempo em que vem uma "garra" para ir até o final - algo que não é experimentado por quem agenda uma cesariana.

Essa história de viver um parto natural é a ideia de a gente escalar uma montanha, um vulcão. A gente pode chegar lá de helicóptero. Agendar uma cesariana, eu vou chegar no mesmo lugar, meu bebê vai nascer e isso é o que mais interessa, é o que a gente mais quer. ${ }^{44}$

A dor, portanto, é um fator de organização da experiência da mulher que pare. A tecnologia médica, por interferir na intensidade ou na qualidade da dor, seria desorganizadora. Ao responder a uma questão sobre o uso da ocitocina (artificial), a palestrante responde que a ocitocina aumenta muito a dor, retirando a mulher de um patamar normal de evolução das contrações - desorganizando por isso a experiência: "o corpo começar a fazer contração que seria lá do final". Do mesmo modo, ao falar sobre a anestesia, afirma que esta tem prós e contras já que, porque elimina a dor, acaba por desorganizar a experiência daquela que pare. 
Embora uma provoque a outra, contração uterina e dor não podem ser tratadas como sinônimos. Para a palestrante, apesar de as dores do parto servirem em grande medida para organizar a experiência corporal (distinguir as fases do trabalho de parto, mostrar as melhores posições a adotar e determinar o momento certo de fazer força), reduzi-las às contrações seria deixar de lado a totalidade da experiência em jogo.

Na verdade, numa contração, a gente vive uma gama de emoções. A Naoli Vinaver, que é uma parteira mexicana [...] diz o seguinte: "mora um universo inteiro dentro de cada contração". Então, numa contração a gente sente dor, mas tem momentos de prazer, numa contração a gente sente medo e, ao mesmo tempo, uma alegria e uma felicidade de que o corpo está funcionando e as coisas estão acontecendo, [...] tem momentos em que a gente tem raiva e tem momentos em que a gente está gritando de amor. Reduzir só à dor é muito pouco.

É importante assinalar que a dor do parto - que vem mesclada com esse efervescente conjunto de experiências emocionais - se diferencia de sofrimento. Este, quando ocorre, é causado pelo excesso de intervenções e pela falta de acolhimento e proteção, a dor transformando-se, neste caso, em um "monstro". De acordo com a palestrante, embora seja muito comum ver mulheres "caindo nesse lugar de vítima" quando sentem que "não conseguem", que "não vão dar conta" de parir (a chamada "hora da covardia"), as parturientes são, em essência, "muito maiores que a dor" produzida pelo corpo - "[nosso corpo] foi feito para procriar, a gente foi feita pra isso, a gente tem essa força aqui dentro". Em outros termos, ser guiada pela dor e, ao mesmo tempo, ultrapassá-la, é o caminho do bom parto.

\section{Considerações finais}

Como afirmamos mais acima, o ideário do parto humanizado caracteriza-se por fazer determinadas bricolagens: entre ciência e concepções alternativas do mundo, e entre tradição e modernidade. No primeiro caso - ciência e perspectivas alternativas - vimos como o ideário analisado calca-se numa severa crítica à medicina e à medicalização do par gravidez/ parto, mas, para fazê-lo, apoia-se na medicina baseada em evidências. É comum nas redes de mulheres partidárias do parto humanizado a busca pela indicação de artigos científicos que fundamentem, em face de mães ou familiares recalcitrantes, suas escolhas. Ou seja, temos aí uma postura antimedicina que não é anticiência. Pelo contrário, a ciência é uma aliada, acionada para legitimar um ideário específico. 
Ao mesmo tempo, a adoção de uma postura reverente diante da ciência não se opõe à aceitação de concepções às vezes francamente esotéricas, tais como o "sagrado feminino". ${ }^{45}$ Em sua observação participante em um curso de formação de doulas, Silva observou que o grupo mostrou-se, por um lado, extremamente participativo durante as atividades práticas e as vivências propostas pelas coordenadoras, compartilhando experiências pessoais, sensações e sentimentos; por outro lado, quando um médico veio ministrar uma aula de formato bem tradicional sobre "medicina baseada em evidências", as participantes assistiram caladas e atentas, sem esboçar dúvidas ou levantar perguntas. Mesmo diante das indagações do palestrante sobre possíveis dúvidas acerca do que estava sendo exposto, ninguém se manifestou abertamente; nesses momentos, só era possível escutar murmúrios entre as alunas (Silva 2017). Uma curiosa mistura de aprendizado "incorporado" pela via das vivências, ou seja, através do corpo e das emoções, e um aprendizado absolutamente tradicional, pela via mental-cognitiva, através da exposição pedagógica de uma autoridade médico-científica.

O que estamos aqui chamando de "visões alternativas" inclui a aproximação com culturas tidas como tradicionais, o que se articula à crítica aos valores materialistas e racionalizantes da civilização ocidental, nas quais corpo e mente - ou espírito - não são vividos e vistos de forma separada ou oposta, como é o caso da medicina. Podemos perceber aí uma espécie de oposição entre cultura "boa" - dos povos "primitivos" e/ou "tradicionais" - e cultura "ruim", representada pelo Ocidente e sua medicina, exceção feita à ciência. A oposição natureza versus cultura, que também atravessa todo o ideário, portanto, se complexifica.

A mulher que busca parir de forma natural, livre do aparato tecnológico da medicina, se aproxima da cultura "boa" dos povos tradicionais e, ao fazê-lo, dá livre curso à sua natureza propriamente feminina. Porque o corpo, se deixarmos que siga seus movimentos naturais sem ser reprimido pelo aparato médico, sabe parir. Neste sentido, a mulher (tendo desaprendido os preconceitos inculcados pela cultura "ruim") sabe corporalmente parir. Lidar com a dor, suportá-la e superá-la, indo "além dos seus limites", fazem parte dessa sabedoria.

O parto funciona, assim, como uma espécie de bildung corporal, uma construção de si que passa pela descoberta, através da experiência do corpo, de um saber instintivo que estava lá o tempo todo - que sempre esteve lá, desde tempos imemoriais, como demonstram as "culturas tradicionais". Uma sabedoria que é própria do corpo da mulher e é, sobretudo, empoderadora.

Trata-se, desta forma, de uma transformação de si que empodera a mulher, devolvendo seu poder de agir retirado pela medicina e a afirma como dona do seu próprio corpo. É essencial ressaltar o papel da dor nesse 
processo. As categorias que surgem nos discursos acerca da experiência do parto - coragem, bravura, guerreira, leoa - expressam fortemente uma noção de poder, força e potência, que passa necessariamente pela dor e por sua superação. A coragem de encarar e suportar a dor em nome do filho que virá - à semelhança dos ritos de passagem de sociedades tribais em que o fato de suportar a dor infligida durante o ritual é parte integrante da nova identidade do sujeito - parece-nos ser um elemento articulador central desse tornar-se mãe. A indissociabilidade entre a atitude perante a dor e a transformação de si através da experiência do parto aparece, embora de forma oblíqua, neste texto encontrado no e-book Dor do parto, como aprender com ela.

Vemos mulheres fugindo da experiência do parto pelo medo da dor, mas não é o medo da dor que assombra. É o medo de uma experiência muito, mas muito profunda, de mergulho dentro de si, para um lugar que é essencialmente feminino, desconhecido, e com muitas coisas a serem descobertas, enfrentadas, abraçadas, choradas, trazidas à tona. É o medo de uma experiência desconhecida e da qual não temos o controle. O medo maior é o da transformação que o parto irá trazer, de morrer uma parte da mulher-filha, para nascer mulher-mãe (Moraes s/d).

Parece-nos, portanto, que esta dor, ressignificada no ideário do parto humanizado mediante as diversas estratégias aqui esboçadas, componente intrínseca desta experiência de renascimento, é um valor fundante da nova identidade da mulher-mãe.

Recebido em: 16 de janeiro de 2019

Aprovado em: 30 de maio de 2019

Jane Russo é Doutora em Antropologia Social - Museu Nacional/UFRJ, professora titular do Programa de Pós-graduação em Saúde Coletiva do Instituto de Medicina Social / UERJ.

ORCID https://orcid.org/0000-0002-4383-334X

E-mail: jane.russo@gmail.com

Marina Nucci é graduada em Ciências Sociais (UFRJ), Mestre e Doutora em Saúde Coletiva (IMS/ UERJ). Atualmente desenvolve pesquisa de pós-doutorado no Instituto de Medicina Social (IMS/ UERJ). Bolsista Faperj Pós-doc Nota 10. ORCID https://orcid.org/0000-0003-3465-9201

E-mail: marinanucci@gmail.com 
Fernanda Loureiro Silva é doutoranda do Programa de Pós-Graduação em Saúde Coletiva - IMS/UERJ.

ORCID https://orcid.org/0000-0002-5520-4647

E-mail: fernandaloureirosilva@gmail.com

Lilian K. Chazan é médica, psicanalista SBPRJ, Doutora em Saúde Coletiva (IMS/ UERJ), realizou pesquisa de pós-doutorado no Instituto de Medicina Social (IMS/ UERJ).

ORCID https://orcid.org/0000-0002-6950-3197

E-mail: liliankc@gmail.com

\section{Notas}

* Este artigo é fruto do trabalho coletivo de um grupo de discussão e pesquisa sobre o parto humanizado que se reúne no IMS há cerca de dois anos sob a coor-


doutorado do PPGSC para sua dissertação de mestrado (Fernanda Loureiro Silva) e uma bolsista de pós-doutorado do mesmo programa (Marina Nucci) origina-se de listas de discussão e blogs da internet, além de filmes e vídeos disponibilizados para o grande público. Ao grupo juntou-se Lilian K. Chazan, cuja pesquisa de doutorado sobre a história do parto medicalizado foi fundamental para a discussão aqui travada. Agradecemos a Roberta Dieguez, Aymara Montezuma e Munique Pontes, que acompanharam a escrita do artigo fazendo sugestões sempre pertinentes e valiosas. Agradecemos ainda a Livi Faro pela leitura cuidadosa das últimas versões do artigo, contribuindo grandemente para sua estruturação final.

1 Com base na bibliografia consultada sobre o movimento pela humanização da assistência ao parto no Brasil, não é possível afirmar uma data precisa para seu início. Diniz (2005) afirma que ele começou ainda na década de 1970, no próprio campo da obstetrícia, a partir de profissionais dissidentes, como Galba de Araújo e Moisés Paciornick, e grupos de terapias alternativas, como o Instituto Aurora. Já Tornquist (2002) constata que é possível falar de um movimento social atuante nos anos 1980, década que marca o surgimento de algumas associações e redes de movimentos identificados pela crítica ao modelo hegemônico de atenção ao parto, como o Coletivo Feminista Sexualidade e Saúde, a Associação Comunitária Monte Azul e os grupos Curumim e Cais do Parto.

2 No Brasil, políticas de saúde governamentais têm apresentado sucessivas estratégias para qualificar o atendimento ao parto e redução de intervenções acompanhando as diretrizes da OMS. Exemplos dessas ações são o Programa de Humanização no Pré-Natal e Nascimento (PHPN), instituído no ano 2000 com o objetivo de reorganizar a assistência obstétrica e garantir o acesso das mulheres a serviços de qualidade, e a Rede Cegonha, criada em 2011 com o objetivo de implementar um "novo modelo" de atenção ao parto e à saúde da criança. 
3 Obstetras, enfermeiras, parteiras, pediatras, epidemiologistas, sociólogos, psicólogos, economistas e gestores de saúde.

4 No original, Care in Normal Birth: a practical guide.

5 As entrevistas e o curso de formação de doulas fazem parte do material empírico levantado por uma das autoras para sua dissertação de mestrado (Silva 2017). Projeto de pesquisa aprovado pelo Comitê de Ética do Instituto de Medicina Social-UERJ. CAAE: 55694916.5.0000.5260. Número do Parecer: 1.663.859.

6 Os termos "medicalização" e "desmedicalização" são amplamente usados na literatura socioantropológica sobre medicina e saúde desde Foucault nos anos 1960. Ver em especial o livro já clássico de Peter Conrad, The medicalization of society (2007). Zorzanelli, Ortega e Bezerra Jr. (2014) chamam a atenção para um uso excessivamente genérico do termo "medicalização" - especialmente como uma crítica ao poder médico. Tal uso, conforme assinalado por estes autores, obscurece as irregularidades do processo de medicalização e os diferentes níveis de sua ocorrência, prejudicando, assim, a compreensão de nuances que estão implicadas em um contexto social mais complexo, no qual agentes médicos e não médicos estão em constante interação, significando e ressignificando suas ações.

7 Pode ser até mesmo incorporada como parte do jogo erótico, como no caso do BDSM (Ver Zilli 2018).

8 Em Gênesis 3, Deus diz à mulher após ela ter levado o homem a comer a maçã do conhecimento: "Multiplicarei os sofrimentos de teu parto; darás à luz com dores, teus desejos te impelirão para o teu marido e tu estarás sob o seu domínio" (Genesis 3 14-16). Ver em: https://www.bibliaonline.com.br/vc/gn/3/14-16+

9 Tradução nossa, como todas a seguir. No original: “[...] acknowledges the fact that the ontology of pain is never stable. As historians of Science never tire of repeating, scientific practice is social action. In other words, identifying the characteristics of pain involves the labor of philosophers, scientists, and clinicians, as much as it does historians. We invent, rather that discover, pain" (Bourke 2014:12).

10 No original: "in the sense that people are active in its construction in sensual, cognitive and motivational terms" (Bourke 2014: 16).

11 No original: "Another way of making this point is to argue that pain only exists in the act of evaluating it" (Bourke 2014: 15).

12 Reconhecemos que há inúmeros estudos antropológicos acerca da dor. Neste trabalho, tendo em vista seu escopo limitado, optamos por não apresentar um levantamento exaustivo de tais estudos, buscando fundamentar nossa análise na categoria analítica "dor-como-evento" proposta por Joanna Bourke (2014).

13 No original: "Concerns about the democratic distribution of happiness, which would make pain relief a 'legitimate goal', arose during the enlightenment" (Bourke 2014:273). 
14 No original: "Pain and pleasure were Romantic preoccupations, which provided the social and ideological conditions necessary to pursue pain relief" (Bourke 2014:273).

15 No original: "The 'unnaturalness' of dulling the senses encouraged these doubts about the value of eradicating pain. After all, wasn't sensation... a natural function of the living organism', asked a physician in 1851? To 'suspend it by artificial agency is to set at nought the ordinances of nature', he warned" (Bourke 2014:279).

16 No original: "Might the availability of anaesthetics eradicate the 'boldest and manliest qualities' from the surgical fraternity, making them mere 'puddlers', one physician pondered?" (Bourke 2014:280).

17 No original: "In the words of an article entitled 'How to endure pain [...], 'every one should train himself to bear up bravely under a certain amount of suffering. [...] Indeed, it was the duty of physicians and surgeons to bolster the courage of patients. In the words of a cancer surgeon who advocated cauterization, 'its moral "final cause" was to develop... heroism in them!"' (Bourke 2014:281).

18 À estruturação da obstetrícia como especialidade corresponde também uma construção social fragmentada da mulher, de sua vida e de seu corpo. Conforme aponta Chazan, "Nos Estados Unidos, as práticas desenvolvidas pela especialidade rapidamente difundiram-se e tornaram-se rotina em todos os partos" (Chazan 2005:98-100, grifo da autora).

19 No Brasil, o uso do termo "humanização" no parto parece datar do início do século XX, sendo utilizado por Fernando Magalhães (o "Pai da Obstetrícia Brasileira") e por seu discípulo Jorge de Rezende (uma referência ainda nos dias atuais) com um sentido diverso do contemporâneo. Para ambos, a narcose e o uso de fórceps eram instrumentos "humanizadores" da assistência aos partos (Diniz 2005).

20 Publicado na França em 1974 com o título Pour une naissance sans violence.

21 Isto é, manuais que, apesar de apresentarem informações e conselhos sobre gravidez, parto e puerpério, não prescrevem (ou procuram não prescrever) comportamentos ou atitudes.

22 Bildung é um conceito que emerge em fins do século XVIII no Romantismo alemão, referido à formação intelectual do indivíduo, ao autocultivo e ao aperfeiçoamento de si, interiorizado (Elias 1993).

23 Na perspectiva da "Medicina baseada em evidências" (MBE), a medicina tradicional teria práticas calcadas em valores extracientíficos. A corrente da MBE preconiza, portanto, uma reformulação da medicina, abandonando práticas "ultrapassadas", substituindo-as por outras respaldadas por pesquisas científicas.

24 Em sua pesquisa com grupos de gestantes tal como eram realizados no início dos anos 1980, Anna Carolina Lo Bianco se refere a uma "medicalização de segundo grau", um tipo de socialização que implica maior envolvimento com o paradigma médico, reforçando seu papel como modelador das experiências de gravidez e de parto (Lo Bianco 1983). 
25 Alzuguir e Nucci (2015).

26 A ocitocina, hormônio produzido pela neuro-hipófise e responsável pelas contrações uterinas (e pela ejeção do leite), foi sintetizada nos anos 1950 e utilizada em obstetrícia para induzir e/ou acelerar o parto. Foi recuperada pelo movimento do parto humanizado como "hormônio do amor". Em seu livro A cientificação do amor (2000), Michel Odent argumenta que o amor materno, induzido hormonalmente através da ocitocina produzida pelo corpo feminino, seria o protótipo de todas as formas de amar. Esta ideia aparece também com frequência no discurso de adeptas e ativistas do parto humanizado, sendo comum o uso de expressões como "estou ocitocinada" para se referir a uma experiência feliz ou emocionante (Alzuguir \& Nucci 2015; sobre as pesquisas clínicas com ocitocina, ver Rohden \& Alzuguir 2016).

27 Sites examinados: www.partodoprincipio.com.br; https://mundodelilica. wixsite.com; www.wanessapickler.com; https://alemdolhar.com.br; www.despertardoparto.com.br

28 Lembramos aqui a relação que surge na já citada pesquisa de Conceição com ultramaratonistas entre, de um lado, a experiência e o manejo da dor e, de outro, o aprimoramento de si (Conceição 2018).

29 A respeito do conceito de enquadramento, ver Goffman (1974).

30 Mariana Pulhez (2013) observa como a construção das denúncias de violência obstétrica, por parte das ativistas pelo parto humanizado, se dá através de um processo que procura alterar perspectivas e noções daquilo que seria constitutivo de um parto. Nesse processo, intervenções e procedimentos obstétricos utilizados até então como rotina durante o parto - como a episiotomia ou a manobra de Kristeller, por exemplo - passam a ser vistos como forma de violência.

31 A categoria "cesárea eletiva", ou "desnecesárea", nesse contexto, refere-se à cirurgia que é agendada previamente e feita mesmo que não haja indicações clínicas para a sua realização.

32 Expressão utilizada pelo movimento para as escolhas feitas por mulheres que desconhecem as evidências científicas desse campo.

33 Essa diferenciação também foi observada por Rezende (2012) em sua pesquisa em um grupo de mulheres gestantes, para o qual passar por uma cesárea era igualada a "não parir".

34 As diretrizes da OMS quanto à analgesia vêm mudando ao longo dos anos: em 1985, recomendava-se que a administração rotineira de analgésicos ou anestésicos deveria ser evitada, em 2018, passam a ser recomendados para a mulheres saudáveis que solicitam alívio da dor.

35 Incisão cirúrgica na região do períneo, visando ao alargamento do canal de parto.

36 Lavagem intestinal. 
37 Raspagem de pelos para procedimentos cirúrgicos; no caso em questão, implica a raspagem de toda a região genital.

38 A posição litotômica consiste no posicionamento da mulher em decúbito dorsal, com a cabeça e os ombros ligeiramente elevados, e as pernas flexionadas, afastadas e suspensas sobre perneiras. Vale observar que, em conjunto com os procedimentos anteriores (notas 36 a 38), mesmo que no decorrer de uma parturição não cirúrgica, estas medidas implicitamente conotam a perspectiva do parto como um evento médico-cirúrgico.

39 Trata-se de um conjunto de técnicas corporais que visam não à supressão, mas ao alívio da dor, buscando torná-la mais suportável.

40 Esse enquadramento no modo de sentir e, principalmente, de expressar a dor, pode ter sentidos diferentes em contextos sociais distintos, como apontam Aguiar e D'Oliveira (2011). Neste artigo, as autoras apresentam e discutem os dados de uma pesquisa sobre violência institucional em maternidades públicas no município de São Paulo.

41 A aula aconteceu em setembro de 2018 e teve mais de 3.000 inscritos (não foi possível saber quantos estavam acompanhando ao vivo). A palestrante, com suas duas assessoras, respondia às mensagens de texto que chegavam durante a aula enviadas pelos participantes. Uma delas foi a de um homem, cuja esposa estava em trabalho de parto naquele momento, dizendo que estavam assistindo para aprender a lidar com a dor do parto. A doula, antecipando alguns pontos, deu umas "dicas rápidas", como ficar no chuveiro por longos períodos, ficar na posição de "quatro apoios", utilizar a bola e (ele) fazer massagens nas costas dela.

42 As expressões entre aspas foram utilizadas pela palestrante em sua aula.

43 Todas as citações foram transcritas a partir de uma gravação do curso on-line. Os grifos, portanto, são nossos.

44 Nesta fala subentende-se que a cesariana implica escolher o caminho mais fácil, como alguém que chega ao topo de uma montanha de helicóptero. Sem esforço e sem passar pela experiência de escalar a montanha (ou o vulcão). Embora a palestrante diga que o nascimento do bebê "é o que mais interessa", evidentemente "escalar um vulcão" é mais heroico e extraordinário do que pegar um helicóptero.

45 O uso da biotecnologia e do discurso científico para sustentar uma experiência romântica e "vital" de si e do próprio corpo - constituindo uma "bricolagem" tal como vislumbramos no caso aqui analisado - foi explorado em outros trabalhos por Russo (ver Russo \& Ponciano 2002, e Russo 2017). 


\section{Referências bibliográficas}

AGUIAR, Janaina Marques \& DOLIVEIRA, Ana Flávia Pires Lucas. 2011. "Violência Institucional em Maternidades Públicas sob a ótica das usuárias". Interface, 15:79-91.

ALZUGUIR, Fernanda \& NUCCI, Marina. 2015. "Maternidade mamífera? Concepções sobre natureza e ciência em uma rede social de mães". Mediações - Revista de Ciências Sociais, 20 (1):217-238.

ARNEY, William Ray. 1982. Power and the Profession of Obstetrics. Chicago: The University of Chicago Press.

BOURKE, Joanna. 2014. The Story of Pain: from prayer to painkillers. Oxford: Oxford University Press.

CARNEIRO, Rosamaria. 2015. Cenas de parto e políticas do corpo. Rio de Janeiro: Editora Fiocruz.

CHAZAN, Lilian K. 2005. “Meio quilo de gente!": Produção do prazer de ver e construção da Pessoa fetal mediada pela ultrassonografia. Um estudo etnográfico em clínicas de imagem na cidade do Rio de Janeiro. Tese de Doutorado em Saúde Coletiva, Universidade do Estado do Rio de Janeiro.

CONCEIÇÃO, Isabel Siqueira. 2018. "A dor e o sofrimento são passageiros, mas o orgulho é eterno": dores e moralidades entre ultramaratonistas do Rio de Janeiro. Dissertação de Mestrado em Saúde Coletiva, Universidade do Estado do Rio de Janeiro.

CONRAD, Peter. 2007. The medicalization of society: On the transformation of human conditions into treatable disorders. Baltimore: Johns Hopkins University Press.

DINIZ, Carmen Simone Grilo. 2005. "Humanização da assistência ao parto no Brasil: os muitos sentidos de um movimento". Ciência \& Saúde Coletiva, 10 (3):627-637.
ELIAS, Norbert. 1993. O processo civilizador. Rio de Janeiro: Jorge Zahar.

FIGUEIRA, S. 1986. "O 'moderno' e o 'arcaico' na nova família brasileira: notas sobre a dimensão invisível da mudança social". In: _. Uma Nova Família: o moderno e o arcaico na família de classe média brasileira. Rio de Janeiro: Jorge Zahar. pp. 11-30.

GOFFMAN, Erving. 1974. Frame Analysis: An Essay on the Organization of Experience. Boston: Northeastern University Press.

HELMAN, Cecil. 2007. "Pain and Culture". In: . Culture, Health and Illness. London: Hodder Arnold. pp. 185-195.

HIRSCH, Olívia. 2015. "O parto 'natural' e 'humanizado' na visão de mulheres de camadas médias e populares no Rio de Janeiro". Civitas, 15 (2):229249.

LE BRETON, David. 2013. Antropologia da dor. São Paulo: Editora Unifesp.

LO BIANCO, Anna Carolina. 1983. The medical ordering of early moderhood: two London groups compared. Tese de Doutorado em Psicologia, Chelsea College.

MENDONÇA, Sara Sousa. 2018. Parir na Maria Amélia: uma etnografia dos dilemas, possibilidades e disputas da humanização em uma maternidade pública carioca. Tese de Doutorado em Antropologia, Universidade Fluminense.

MORAES, Eleonora. s/d. Dor no parto: como aprender com ela (ebook).

ODENT, Michel. 2000. A cientificação do amor. São Paulo: Terceira Margem.

PULHEZ, Mariana Marques. 2013. "'Parem a violência obstétrica': a construção das noções de 'violência' e 'vítima' nas experiências de parto". RBSE - Revista Brasileira de Sociologia da Emoção, 12 (35):544-564. 
REZENDE, Claudia Barcellos. 2015. "O parto em contexto: Narrativas da gravidez entre gestantes no Rio de Janeiro". Civitas, 15 (2):214-228. ."Emoção, corpo e moral em grupos de gestante". 2012. RBSE. Revista Brasileira de Sociologia da Emoção, 11:830-849.

ROHDEN, Fabíola. 2000. Uma ciência da diferença: sexo, contracepção e natalidade na medicina da mulher. Tese de Doutorado em Antropologia Social, Universidade Federal do Rio de Janeiro.

ROHDEN, Fabiola \& ALZUGUIR, Fernanda. 2016. "Desvendando sexos, produzindo gêneros e medicamentos: a promoção das descobertas científicas em torno da ocitocina". Cadernos Pagu, 48:e164802.

RUSSO, Jane \& PONCIANO, Edna. 2002. "O sujeito da Neurociência: da naturalização do homem ao re-encantamento da natureza". Physis, 12 (2):54-76.

RUSSO, Jane. 2017. “Do psíquico ao somático: notas sobre a reconfiguração do self contemporâneo". História, Ciências, Saúde - Manguinhos, 24:157-169.

SALEM, Tania. 1987. Sobre o "casal grávido": incursão em um universo ético. Tese de Doutorado em Antropologia Social, Universidade Federal do Rio de Janeiro.

. 2007. O casal grávido: Disposições e dilemas da parceria igualitária. Rio de Janeiro: FGV Editora.

SARTI, Cynthia. 2001. "A dor, o indivíduo e a cultura". Saúde e Sociedade, 10 (1):3-13.

SHORTER, Edward. 1997. Women's Bodies: A Social History of Women's Encounter with Health, Ill-Health, and Medicine. New Brunswick \& London: Transaction Publishers.
SILVA, Fernanda Loureiro. 2017. Sobre a "porta que abre por dentro": análise cultural do processo de formação de doulas para a assistência ao parto no Brasil. Dissertação de Mestrado em Saúde Coletiva, Universidade do Estado do Rio de Janeiro.

SOUZA, Heloisa. 2005. A arte de nascer em casa: Um olhar antropológico sobre a ética, a estética e a sociabilidade no parto domiciliar contemporâneo. Dissertação de Mestrado em Antropologia Social, Universidade Federal de Santa Catarina.

TORNQUIST, Carmen Suzana. 2002. Armadilhas da Nova Era: natureza e maternidade no ideário da humanização do parto. Revista Estudos Feministas, 10 (2):483-492. 2004. Parto e poder: O movimento pela humanização do parto no Brasil. Tese de Doutorado em Antropologia Social, Universidade Federal de Santa Catarina.

TURNER, Victor. 1987. The anthropology of performance. New York: PAJ Publications.

WHO. 1985. "Appropriate Technology for Birth". Lancet, 326 (8452):436-437. . 1996. Care in Normal Birth: a practical guide. Safe Motherhood. Genebra: World Health Organization. 2018. Intrapartum care for a positive childbirth experience. Geneva: World Health Organization.

ZILLI, Bruno. 2018. A perversão domesticada: BDSM e consentimento sexual. Rio de Janeiro: Papéis Selvagens.

ZORZANELLI, Rafaela; ORTEGA, Francisco \& BEZERRA Jr, Benilton. 2014. “Um panorama sobre as variações em torno do conceito de medicalização entre 1950-2010". Ciência \& Saúde Coletiva, 19 (6):1859-1868. 


\section{ESCALANDO VULCÕES:}

\section{A RELEITURA DA DOR NO \\ PARTO HUM ANIZADO}

\section{Resumo}

Recentemente, o chamado "parto humanizado" tem sido objeto de inúmeros estudos, configurando um movimento social que se expressa publicamente contra o parto hospitalar tradicional, incentivando o uso de práticas "humanizadas" que seriam mais adequadas à fisiologia do parto. Neste trabalho discutimos a forma como esta proposta de um novo modo de parir se articula com uma interpretação renovada da dor do parto. Para nossa análise, utilizamos entrevistas, aulas de capacitação para doulas, blogs, sites, vídeos, filmes e um e-book. Nosso foco prioritário foi o material acessado através da internet, já que boa parte das informações e reivindicações associadas ao movimento circula em redes virtuais. Observamos como o ideário do parto humanizado caracteriza-se por fazer determinadas bricolagens: entre ciência e concepções alternativas do mundo; entre tradição e modernidade. Procuramos mostrar como a dor, ressignificada nesse ideário, torna-se uma componente intrínseca da experiência de dar à luz, e é um valor fundante da nova identidade da mulher-mãe.

Palavras-chave: Maternidade; Medicalização; Parto humanizado; Dor.
ESCALANDO VOLCANES:

\section{LA RELECTURA DEL DOLOR EN EL PARTO HUMANIZADO}

\section{Resumen}

El llamado "parto humanizado" viene siendo objeto de innumerables estudios, configurando un movimiento social que se expresa contra el parto tradicional en el hospital, incentivando el uso de prácticas "humanizadas" que serían más adecuadas a la fisiología del parto. Este trabajo discute como la propuesta de un nuevo modo de parir se articula con una interpretación renovada del dolor del parto. Para este análisis, utilizamos entrevistas, clases de capacitación para doulas, blogs, sitios de internet, videos y un e-book. Nuestro foco principal fue el material encontrado en internet, ya que buena parte de las informaciones y reivindicaciones asociadas al movimiento circulan en redes virtuales. Observamos que este ideario se caracteriza por hacer determinados entramados: entre ciencia y concepciones alternativas del mundo; entre tradición y modernidad. Buscamos mostrar cómo la resignificación del dolor, componente intrínseco de esta experiencia de parto, es un valor fundante de la nueva identidad de la mujer-madre. Palabras clave: Maternidad; Medicalización; Parto humanizado; Dolor. 
CLIM BING VOLCANOES:

REREADING PAIN IN

HUM ANIZED CHILDBIRTH

\section{Abstract}

Recently, the so-called "humanized childbirth" has been the subject of numerous studies, amounting to a social movement that speaks publicly against traditional birth, encouraging the use of "humanized" practices that are more adequate to the physiology of childbirth. In this article we discuss the way this new form of giving birth articulates itself with a renewed interpretation of the pain normally associated with childbirth. In our analysis we use interviews, training classes for doulas, blogs, websites, videos, movies and an e-book. We chose to focus primarily on the material accessed through the Internet, since the information and the political claims associated with the movement circulate mainly within virtual networks. We argue that the ideology of humanized childbirth is characterized by bricolages: between science and alternative conceptions of the world; between tradition and modernity. We seek to show how pain, re-signified by this new ideal, seems to be an intrinsic component of the experience of giving birth, and is a key value of the new identity of the woman who becomes a mother.

Key words: Motherhood; Medicalization; Humanized birth; Pain. 